\title{
Bone health in the prostate cancer patient receiving androgen deprivation therapy: a review of present and future management options
}

\author{
Blair Egerdie, BSc(ChemEng), MD, FRCSC; ${ }^{*}$ Fred Saad, MD, FRCS ${ }^{\dagger}$
}

\begin{abstract}
Osteoporosis and bone fractures are frequently overlooked complications of androgen deprivation therapy in men with nonmetastatic prostate cancer. All such patients should have their bone mineral density (BMD) monitored and be offered preventive measures, such as calcium and vitamin D supplementation; patients with low BMD should be offered treatment. Several agents, including bisphosphonates, are available (although this use is currently offlabel), and upcoming treatments, such as denosumab and toremifene, have shown promise in reducing fracture risk in these patients.
\end{abstract}

\section{Résumé}

L'ostéoporose et les fractures osseuses sont des complications souvent négligées du traitement antiandrogénique chez les hommes atteints d'un cancer de la prostate non métastatique. La teneur minérale des os de ces patients devrait être surveillée, et des mesures préventives, comme la prise de suppléments de calcium et de vitamine $D$, devraient être offertes. Les patients présentant une faible teneur minérale des os devraient se voir offrir un traitement approprié. Plusieurs agents, y compris des bisphosphonates, sont offerts sur le marché (quoique cette indication ne soit pas officiellement approuvée à l'heure actuelle), et des traitements en cours d'étude, comme le dénosumab et le torémifène, se sont révélés prometteurs dans la réduction du risque de fracture chez ces patients.

Can Urol Assoc J 2010;4(2):129-35

\section{Why should bone loss concern urologists?}

Androgen deprivation therapy (ADT) is increasingly being prescribed both for men with locally advanced or high-risk nonmetastatic prostate cancer and for those with recurrent disease. ${ }^{1,2}$ With this increased exposure to ADT, clinicians have seen the emergence of longer-term treatment complications, including osteoporosis and osteopenia. Although osteoporosis is generally less frequent in men, it is increasingly recognized as a source of substantial morbidity and even mortality in the aging male. Men suffer one third of all hip fractures. In a Canadian study of 3981 hip fracture patients, the 1-year mortality rate among men over 60 after a hip fracture was $37.5 \%$, exceeding that among women $(28.3 \% ; p<0.001){ }^{3}$ Osteoporotic vertebral fractures have a radiological prevalence of up to $50 \%$ in both sexes; they often cause chronic pain, and even clinically silent fractures are associated with increased risks of future fracture (both vertebral and hip), kyphosis, restricted lung function, impaired activities of daily living and even increased mortality. ${ }^{4}$ A study of Canadian prostate cancer patients who were orchiectomized found that their 5-year risks of vertebral and hip fractures were 2.2-fold higher than those of patients who had not been orchiectomized $(p<0.001$ for both). ${ }^{5}$ Further, a claims-based study carried out in Ontario compared 19079 men aged at least 66 years with prostate cancer who had used ADT for at least 6 months or who had undergone orchiectomy with matched controls who had not received ADT; the former group had a significantly increased risk of fragility fractures (HR $1.65 ; 95 \% \mathrm{Cl}$ 1.53-1.77). ${ }^{6}$ Among prostate cancer patients receiving ADT, induced hypogonadism is a major risk factor for osteoporosis and, hence, of fracture. Fractures also independently predict diminished survival in prostate cancer patients on ADT. In one retrospective study, a history of fracture since the diagnosis of prostate cancer decreased median overall survival from 160 months to 121 months $(p=0.04){ }^{7}$

Despite these potentially serious complications, osteoporosis and osteopenia are greatly underdiagnosed and undertreated in this population. A recent retrospective chart review involving 174 veterans with prostate cancer in New Mexico who were receiving ADT found that only $34 \%$ of those with nonmetastatic disease had received any recommended screening, prophylaxis, or therapy for osteoporosis, and only $13 \%$ had received a dual-energy x-ray absorptiometry (DXA) scan. Many of these patients had additional risk factors for osteoporosis including diabetes, smoking, alcohol use and treatment with corticosteroids. ${ }^{8}$

This overview focuses on cancer-treatment-induced bone loss (CTIBL) in the patient with nonmetastatic prostate cancer. Reflecting the latest research in CTIBL, this article discusses 
mechanisms of bone loss, risk factors, treatment options and offers practical advice for the community urologist regarding the evaluation and management of their prostate cancer patient's bone health.

\section{The RANK/RANKL pathway and the effects of hormonal therapy on bone}

Bones are composed of 2 main types of tissues: cortical bone and trabecular bone. Cortical (compact) bone is $80 \%$ to $90 \%$ calcified and has mainly mechanical and protective functions. Trabecular (cancellous or spongy) bone is only $15 \%$ to $25 \%$ calcified and constitutes only $20 \%$ of the total bone mass, but carries out most of the bone's metabolic function. Bone strength is a function of bone mass and of other parameters including geometry (e.g., the diameter of the cortical bone), material properties (e.g., the quality of the bone matrix and inorganic crystals) and microstructure (e.g., the diameter and interconnectivity of the trabeculae). ${ }^{9}$ The bone mass of a normal adult is the outcome of a dynamic equilibrium between bone formation (mediated by osteoblasts) and bone resorption (mediated by osteoclasts). The function of the latter cells is regulated by a family of proteins that include receptor activator of nuclear factor $\kappa-B$ (RANK), RANK ligand (RANKL) and osteoprotegerin (OPG). Binding of RANKL to RANK on the surfaces of osteoclast precursors will trigger maturation, activation, and prolonged survival of these cells. Thus, RANKL promotes bone resorption. In contrast, OPG is a "decoy receptor" that binds and neutralizes RANKL, thus inhibit-

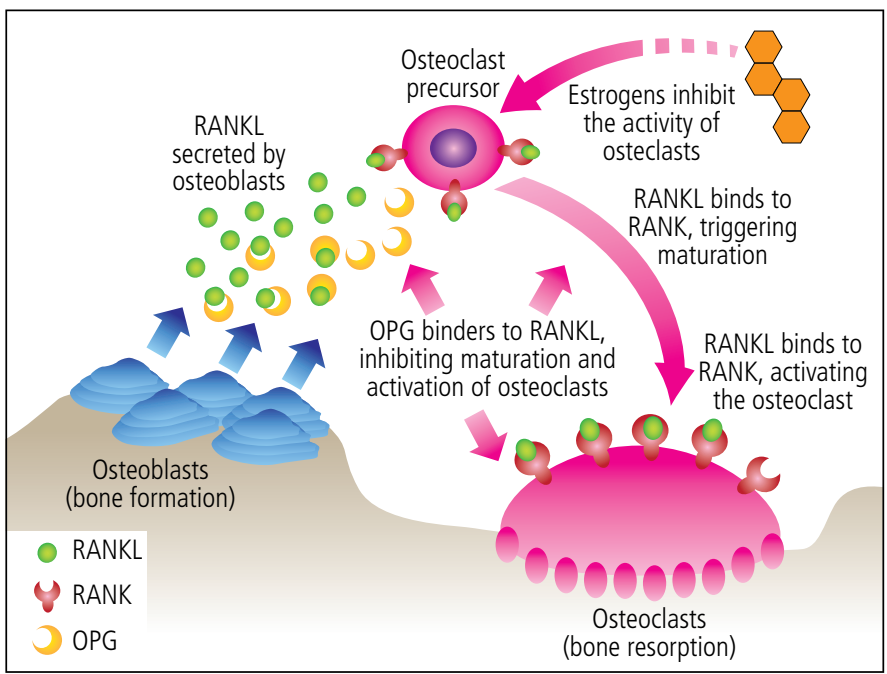

Fig. 1a. Interplay between RANKL and OPG in the control of osteoclast activity. RANKL is expressed by osteoblasts and binds to its specific receptor RANK on the surface of osteoclast precursors, triggering pathways that promote the differentiation, activation and survival of osteoclasts. OPG binds to RANKL and neutralizes it, blocking the differentiation and activation of new osteoclasts and shortening the survival time of existing osteoclasts. Adapted from Boyle WJ, et al. Nature 2003:423:337. ing bone resorption. ${ }^{10}$ There is interplay between RANKL and OPG (Fig. 1a).

The ratio of RANKL to OPG is a critical factor determining the balance between bone resorption and bone formation. Vitamin $\mathrm{D}_{3}$, parathyroid hormone, tumour necrosis factor- $\alpha$ (TNF- $\alpha$ ), activated T-cells, and glucocorticoid therapy all increase this ratio, promoting bone resorption. Estrogen deficiency states (including menopause) also produce osteoporosis because normal levels of $17 \beta$-estradiol inhibit RANKL production and stimulate OPG. ${ }^{10,11}$ Testosterone stimulates osteoblasts, inhibits the apoptosis of both osteoblasts and osteoclasts, and is a precursor of estrogen via aromatization; its net effect is to stimulate bone formation. In males with hypogonadism (whether induced by orchiectomy, ADT, hyperparathyroidism, or other causes), both testosterone and estrogen levels fall, shifting the balance of bone turnover toward resorption (Fig. 1b). ${ }^{12,13}$ It has been hypothesized that several malignancies including prostate and breast cancer and multiple myeloma also promote bone resorption by expressing or stimulating RANKL. ${ }^{10}$

\section{Who is at risk? Who should be screened?}

In its clinical practice guidelines on the diagnosis and management of osteoporosis, the Osteoporosis Society of Canada (OSC) identified 4 robust, independent risk factors for osteoporotic fracture: low bone mineral density (BMD), a prior fragility fracture, age $\geq 65$ and a family history of osteoporosis (Box 1). ${ }^{14}$ In turn, there are also other risk factors for osteoporosis, including lifestyle and dietary factors, and diseases and treatments associated with bone loss (Table 1). ${ }^{14,15}$

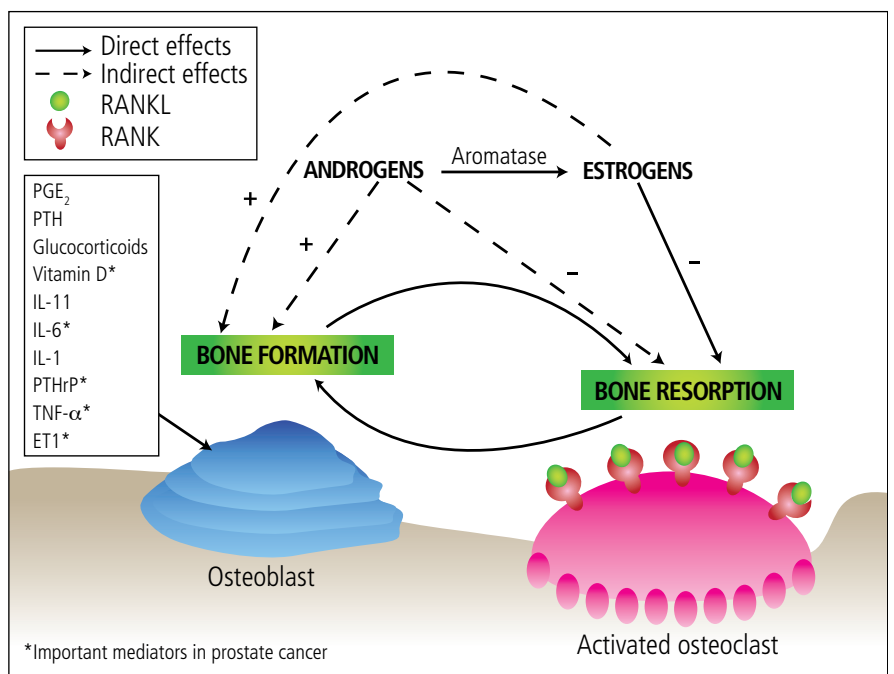

Fig. $\mathbf{1 b}$. Hormonal effects on bone. Estrogen inhibits bone resorption, while androgens promote bone formation. When either androgen or estrogen is deficient (for example, in postmenopausal patients, those taking aromatase inhibitors or men with prostate cancer taking ADT), bone resorption predominates over bone formation, and the net effect is loss of bone. Adapted from Perez EA, et al. Oncology. Williston Park, 2006;1029. 


\section{Box 1. FLAP: four key risk factors for fracture}

Family history of osteoporosis

Low BMD

Age $\geq 65$ years

Prior fragility fracture

Adapted from Brown JP, Josse RG. CMAJ 2002;167(Suppl 10):S1

Prostate cancer itself is associated with osteoporosis, even among ADT-naïve patients without metastatic disease. In a cross-sectional study, $45.2 \%$ of such patients had osteopenia and $35.4 \%$ had osteoporosis even before starting ADT. In addition, prevalence increased with duration of treatment until after 10 years no patient on ADT had a BMD within the normal range (Fig. 2). ${ }^{16}$ Numerous prospective longitudinal studies have confirmed that BMD generally decreases significantly at the spine and hip, particularly during the first year of ADT; reported BMD losses after only 1 year of ADT range up to $4.8 \%$ at the lumbar spine and $3.8 \%$ at total hip. ${ }^{17}$

Systematic retrospective reviews have also shown the association between ADT and increased fracture risk. ${ }^{17,18}$ For example, a large study of Medicare records from 50613 prostate cancer patients in the United States found overall fracture rates of $19.4 \%$ after 5 years among those who received ADT within 6 months of diagnosis and $12.6 \%$ among those who did not $(p<0.001$; Fig. 3$)$. The authors estimated that about 3000 fractures a year were attributable to gonadotropin-releasing hormone $(\mathrm{GnRH})$ agonist use. ${ }^{19}$

Because age and hypogonadism are both considered major risk factors for osteoporosis, all prostate cancer patients beginning ADT should be screened with DXA scans at baseline; anyone aged $\geq 65$ and anyone with kyphosis, back pain, substantial height loss, or other symptoms suggesting vertebral fractures should also be screened with thoracic and lumbar spine x-rays. These recommendations are consistent with those of a recent Canadian review of the diagnosis and management of osteoporosis in men. ${ }^{20}$

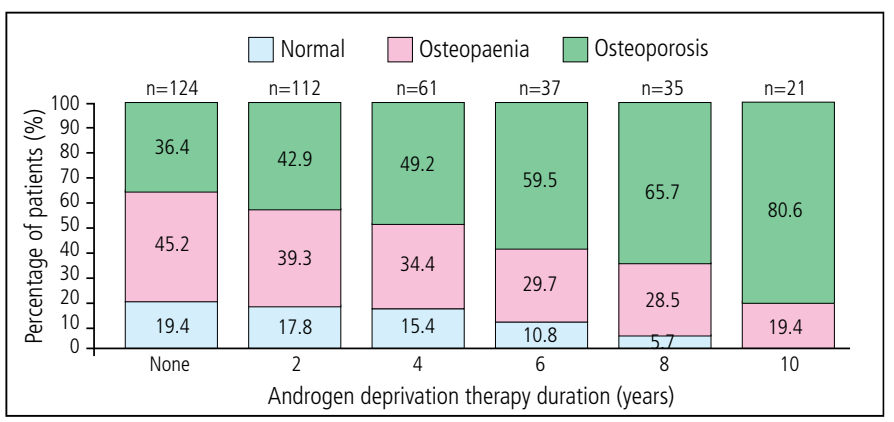

Fig. 2. Prevalence of osteopaenia and osteoporosis among men with nonmetastic prostate cancer: effect of duration of ADT. Printed with permission. Morote J, et al. Urology 2007;69:500.
Table 1. Screening for osteoporosis in men: Who is at risk?

\begin{tabular}{ll} 
Demographic factors & Age $\geq \mathbf{6 5}$ years \\
\hline History & $\begin{array}{l}\text { Family history of osteoporotic fracture } \\
\text { Fragility fracture after age 40 } \\
\text { Significant height loss }\end{array}$ \\
\hline $\begin{array}{l}\text { Lifestyle and } \\
\text { dietary factors }\end{array}$ & $\begin{array}{l}\text { Smoking } \\
\text { Excessive intake of alcohol or caffeine } \\
\text { (>4 cups daily) } \\
\text { Inadequate dietary calcium intake } \\
\text { Weight }<57 \text { kg (or loss of }>10 \% \text { of weigh } \\
\text { at age 25) }\end{array}$ \\
\hline Physical findings & $\begin{array}{l}\text { Vertebral deformity (eg, kyphosis) or } \\
\text { osteopenia evident on x-ray }\end{array}$ \\
Diseases associated & $\begin{array}{l}\text { Prostate cancer } \\
\text { Chronic obstructive pulmonary disease } \\
\text { with bone loss }\end{array}$ \\
$\begin{array}{l}\text { Malabsorption syndrome } \\
\text { Hyperparathyroidism } \\
\text { Hyperthyroidism } \\
\text { Hypogonadism } \\
\text { Rheumatoid arthritis } \\
\text { Renal insufficiency } \\
\text { Vitamin D deficiency }\end{array}$
\end{tabular}

$\begin{array}{ll}\text { Treatments } & \text { Androgen deprivation therapy } \\ \text { associated with } & \text { Anticonvulsants } \\ \text { bone loss } & \text { Heparin } \\ & \text { Systemic glucocorticoids } \\ & \text { (duration > 3 months) }\end{array}$

Printed with permission. Brown JP, Josse RG. CMAJ 2002;167(Suppl 10):S1. Greenspan SL. J Clin Endocrinol Metab 2008;93:2.

\section{Treatment for CTIBL in prostate cancer: current options and new horizons}

\section{Lifestyle measures, calcium and vitamin D supplementation}

Lifestyle modifications to address osteoporosis include exercise, smoking cessation and moderating alcohol and caffeine intake. In addition, men over 50 should have a total of $1500 \mathrm{mg}$ daily of calcium and 800 IU daily of vitamin $\mathrm{D}\left(\mathrm{D}_{3}\right.$ being preferable to $\left.\mathrm{D}_{2}\right) \cdot{ }^{14}$ However, the OSC guidelines state that while adequate calcium and vitamin D (whether dietary or supplemented) are essential adjuncts to prevent and treat osteoporosis, they are insufficient by themselves as treatments.

\section{Bisphosphonates}

Bisphosphonates (BPs) are often used for patients with bone metastases to prevent pathologic fractures, reduce bone pain or control hypercalcaemia, but they are not specifically indicated for the prevention and treatment of CTIBL. Numerous randomized controlled trials have explored the effects of BPs on BMD in the setting of ADT for nonmetastatic prostate 
Table 2. Published randomized controlled trials in the management of cancer-treatment-induced bone loss in prostate cancer patients receiving androgen deprivation therapy

\begin{tabular}{|c|c|c|c|c|c|c|c|}
\hline ADT & $\begin{array}{l}\text { Author } \\
\text { (year) }\end{array}$ & $\mathbf{N}$ & Treatment arms & $\begin{array}{l}\text { Duration of study } \\
\text { follow-up }\end{array}$ & $\begin{array}{l}\text { Key end } \\
\text { point }\end{array}$ & $\begin{array}{l}\text { Main } \\
\text { results* }\end{array}$ & $\begin{array}{l}\text { Adverse } \\
\text { events }\end{array}$ \\
\hline $\begin{array}{l}\text { Bisphosphonates - } \\
\text { alendronate }\end{array}$ & $\begin{array}{c}\text { Greenspan et al. } \\
\text { (2007) }\end{array}$ & 112 & $\begin{array}{l}\text { Alendronate } 70 \text { mg po q } \\
1 \text { week vs. placebo }\end{array}$ & 1 year & BMD & $\begin{array}{c}\text { Alendronate }>\text { placebo } \\
\text { (spine, FN) }\end{array}$ & NSS \\
\hline $\begin{array}{l}\text { Bisphosphonates - } \\
\text { alendronate }\end{array}$ & $\begin{array}{c}\text { Greenspan et al. } \\
(2008)\end{array}$ & 112 & $\begin{array}{l}\text { Continue alendronate } \\
70 \mathrm{mg} \text { po q } 1 \text { week vs. } \\
\text { crossover to placebo vs. } \\
\text { crossover to alendronate }\end{array}$ & $\begin{array}{c}2 \text { years (re- } \\
\text { randomization after } \\
1 \text { year) }\end{array}$ & BMD & $\begin{array}{l}\text { Alendronate/ } \\
\text { alendronate > } \\
\text { alendronate/ } \\
\text { placebo, placebo/ } \\
\text { alendronate } \\
\text { (spine, TH, FN) }\end{array}$ & NSS \\
\hline $\begin{array}{l}\text { Bisphosphonates - } \\
\text { neridronate }\end{array}$ & Morabito et al. (2004) & 48 & $\begin{array}{l}\text { Neridronate } 25 \text { mg IM q } \\
1 \text { month vs. none }\end{array}$ & 1 year & BMD & $\begin{array}{l}\text { Neridronate }>\text { none } \\
\quad(\text { spine, } \mathrm{TH})\end{array}$ & None relevant \\
\hline $\begin{array}{l}\text { Bisphosphonates - } \\
\text { neridronate }\end{array}$ & Magno et al. (2005) & 60 & $\begin{array}{l}\text { Maximal androgen } \\
\text { blockade (A) or } \\
\text { bicalutamide }(B), \text { with } \\
\text { neridronate }\end{array}$ & 1 year & BMD & $\begin{array}{c}\text { Arms with neridronate }> \\
\text { arms without } \\
\text { neridronate }\end{array}$ & None relevant \\
\hline
\end{tabular}

$25 \mathrm{mg}$ IM q 1 month (A2,

B2) or without

(A1, B1) ( $n=15$ each)

\begin{tabular}{|c|c|c|c|c|c|c|c|}
\hline $\begin{array}{l}\text { Bisphosphonates - } \\
\text { pamidronate }\end{array}$ & $\begin{array}{l}\text { Diamond et al. } \\
\text { (2001) }\end{array}$ & 21 & $\begin{array}{c}\text { Pamidronate } 90 \mathrm{mg} \text { IV vs. } \\
\text { placebo (crossover at } \\
6 \text { months) }\end{array}$ & $\begin{array}{c}1 \text { year (crossover at } \\
6 \text { months) }\end{array}$ & BMD & $\begin{array}{c}\text { Pamidronate }>\text { placebo } \\
\text { (spine, FN) }\end{array}$ & Not reported \\
\hline $\begin{array}{l}\text { Bisphosphonates - } \\
\text { pamidronate }\end{array}$ & Smith et al. (2001) & 47 & $\begin{array}{l}\text { Pamidronate } 60 \mathrm{mg} \mathrm{IV} \mathrm{q} \\
3 \text { months vs. none }\end{array}$ & 48 weeks open-label & BMD & $\begin{array}{l}\text { Pamidronate > none } \\
\text { (spine, TH, trochanter) }\end{array}$ & $\begin{array}{c}2 \text { withdrawals } \\
\text { (angiosarcoma, } \\
\text { memory disorder) } \\
\text { in pamidronate } \\
\text { group } \\
3 \text { acute phase } \\
\text { reactions in } \\
\text { pamidronate group }\end{array}$ \\
\hline
\end{tabular}

\begin{tabular}{|c|c|c|c|c|c|c|}
\hline $\begin{array}{l}\text { Bisphosphonates - } \\
\text { zoledronic acid }\end{array}$ & Smith et al. (2003) & 106 & $\begin{array}{l}\text { Zoledronic acid } 4 \mathrm{mg} \mathrm{IV} \mathrm{q} \\
3 \text { months vs. placebo }\end{array}$ & 1 year & BMD & $\begin{array}{c}\text { Zoledronic acid > } \\
\text { placebo (spine, FN, TH) }\end{array}$ \\
\hline $\begin{array}{l}\text { Bisphosphonates - } \\
\text { zoledronic acid }\end{array}$ & Ryan et al. (2006) & 122 & $\begin{array}{l}\text { Zoledronic acid } 4 \mathrm{mg} \mathrm{IV} \mathrm{q} \\
3 \text { months vs. placebo }\end{array}$ & 1 year, double-blind & BMD & $\begin{array}{c}\text { Zoledronic acid > } \\
\text { placebo (spine, FN, } \mathrm{TH} \text { ) }\end{array}$ \\
\hline
\end{tabular}

NSS

Nausea more common in zoledronic acid group

Otherwise, NSS

No mandibular

osteonecrosis seen

\begin{tabular}{|c|c|c|c|c|c|c|c|}
\hline $\begin{array}{l}\text { Bisphosphonates - } \\
\text { zoledronic acid }\end{array}$ & Ryan et al. (2007) & 42 & $\begin{array}{l}\text { Zoledronic acid } 4 \mathrm{mg} \mathrm{IV} \mathrm{q} \\
3 \text { months vs. placebo }\end{array}$ & 1 year, double-blind & BMD & $\begin{array}{l}\text { Zoledronic acid > } \\
\text { placebo (spine, FN) }\end{array}$ & $\begin{array}{l}\text { NSS (1 severe AE } \\
\text { in placebo group) }\end{array}$ \\
\hline $\begin{array}{l}\text { Bisphosphonates - } \\
\text { zoledronic acid }\end{array}$ & $\begin{array}{l}\text { Michaelson et al. } \\
\text { (2007) }\end{array}$ & 40 & $\begin{array}{l}\text { Zoledronic acid } 4 \text { mg IV } \\
\text { (single dose) vs. placebo }\end{array}$ & 1 year & BMD & $\begin{array}{l}\text { Zoledronic acid > } \\
\text { placebo (spine, TH) }\end{array}$ & $\begin{array}{l}\text { No serious } \\
\text { treatment-related } \\
\text { adverse events }\end{array}$ \\
\hline $\begin{array}{l}\text { Bisphosphonates - } \\
\text { zoledronic acid }\end{array}$ & Israeli et al. (2007) & 215 & $\begin{array}{l}\text { Zoledronic acid } 4 \mathrm{mg} \mathrm{IV} \mathrm{q} \\
3 \text { months vs. placebo }\end{array}$ & 1 year & BMD & $\begin{array}{l}\text { Zoledronic acid > } \\
\text { placebo (spine, TH) }\end{array}$ & $\begin{array}{c}\text { NSS } \\
\text { Traumatic fractures } \\
\text { for } 2 \text { in zoledronic } \\
\text { acid group and } 3 \text { in } \\
\text { placebo group } \\
\text { No ONJ }\end{array}$ \\
\hline $\begin{array}{l}\text { SERMs - } \\
\text { raloxifene }\end{array}$ & Smith (2004) & 48 & $\begin{array}{l}\text { Raloxifene } 60 \text { mg daily } \\
\text { vs. none }\end{array}$ & 12 months, open-label & BMD & $\begin{array}{l}\text { Raloxifene }>\text { none } \\
\text { (TH) }\end{array}$ & Well tolerated \\
\hline $\begin{array}{l}\text { SERMs - } \\
\text { toremifene citrate }\end{array}$ & Steiner (2004) & 46 & $\begin{array}{c}\text { Toremifene citrate vs. } \\
\text { placebo }\end{array}$ & 6 months & BMD & Toremifene $>$ placebo & $\begin{array}{c}\text { Also decreased hot } \\
\text { flushes }\end{array}$ \\
\hline $\begin{array}{l}\text { Nonsteroidal } \\
\text { antiandrogens - } \\
\text { bicalutamide }\end{array}$ & Smith (2004) & 52 & $\begin{array}{l}\text { Bicalutamide vs. } \\
\text { leuprolide }\end{array}$ & 12 months, open-label & BMD & $\begin{array}{c}\text { Bicalutamide > } \\
\text { leuprolide } \\
\text { (spine, et al.) }\end{array}$ & $\begin{array}{l}\text { Also decreased fat } \\
\text { mass, fatigue, loss } \\
\text { of libido, hot } \\
\text { flushes }\end{array}$ \\
\hline $\begin{array}{l}\text { Antibodies directed } \\
\text { against RANKL - } \\
\text { denosumab }\end{array}$ & Smith et al. (2009) & 1468 & $\begin{array}{l}\text { Denosumab } 60 \text { mg s.c. q } \\
6 \text { months vs. placebo }\end{array}$ & $\begin{array}{l}36 \text { months, double- } \\
\text { blind }\end{array}$ & BMD & $\begin{array}{l}\text { Denosumab > placebo } \\
\text { (lumbar spine, total hip, } \\
\text { femoral neck, } \\
\text { distal radius) }\end{array}$ & NSS \\
\hline
\end{tabular}

$\mathrm{BMD}$ = bone mineral density; $\mathrm{FN}$ = femoral neck; $\mathrm{NSS}$ = not statistically significant; ONJ = osteonecrosis of the jaw; TH = total hip; $\mathrm{SERMs}=$ selective estrogen receptor modulators; RANKL = receptor activator for nuclear factor $\mathrm{K} B$ ligand. ${ }^{*} \mathrm{~A}>\mathrm{B}$ means A produced a significantly better result than B. Printed with permission. Saad F, et al. $J$ Clin Oncol 2008;26:1. 


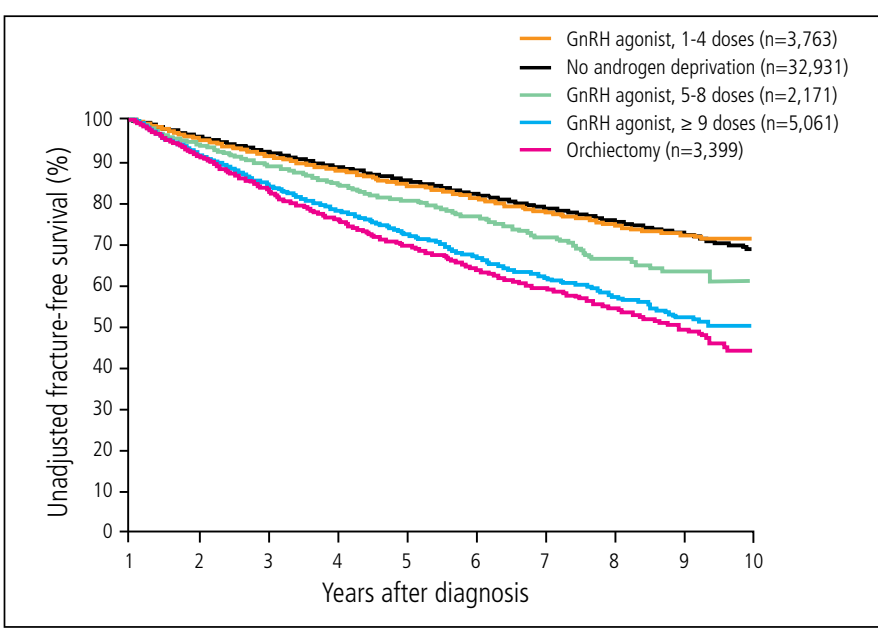

Fig. 3. Prevalence of fractures in men with prostate cancer: effect of ADT type and dose. Unadjusted fracture-free survival among patients with prostate cancer, according to androgen-deprivation therapy. The survival curves start at 12 months after diagnosis and androgen deprivation was initiated within 6 months after diagnosis. GnRH denotes gonadotropin-releasing hormone. The number of doses is the number administered within 12 months after diagnosis. Printed with permission. Shahinian VB, et al. N Engl J Med 2005;352:154.

cancer (Table 2), ${ }^{21-34}$ but to date none have had sufficient power to demonstrate a reduction in fractures. These trials demonstrate clearly that BPs are effective in reducing BMD loss associated with ADT for at least 1 year. ${ }^{17}$ Hence, the OSC guidelines (and many others) recommend BPs as firstline agents. ${ }^{14,17,18} \mathrm{~A}$ large study is underway evaluating the effects of zoledronic acid-one of the most potent BPson fracture risk and BMD in 1272 men with early-stage prostate cancer who are receiving a $\mathrm{GnRH}$ agonist. ${ }^{35}$

Bisphosphonates have some limitations. First, long-term efficacy data are sparse-a key concern, given that prostate cancer patients are likely to receive ADT for many years. Oral BPs are poorly absorbed, must be taken on an empty stomach and often produce gastrointestinal side effects. Thus, long-term adherence to oral BPs tends to be poor; studies of 1-year adherence to BPs in postmenopausal women have found adherence rates under $60 \%$ even with oncemonthly treatments. ${ }^{36}$ Due to lack of compliance, intravenous BPs are preferred to oral BPs; influenza-like acute phase reactions on initial administration are common but mild, while acute tubular necrosis is rare but serious. Finally, osteonecrosis of the jaw (characterized by exposed bone in the maxillofacial region that has not healed within 8 weeks) is probably a very rare adverse event $(1 / 10000$ to less than 1/100 000 patient treatment years) when BPs are used at doses for treatment or prevention of osteoporosis. While the precise etiology of osteonecrosis of the jaw is unknown, previous dental pathology and dental surgery or dentures are known risk factors. Preventive measures include good oral hygiene, regular dental follow-up and avoidance of invasive dental procedures, when possible. ${ }^{37-40}$

\section{Table 3. A simple algorithm for the management of cancer- treatment-induced bone loss in patients with nonmetastatic prostate cancer receiving androgen deprivation therapy}

\begin{tabular}{ll} 
DXA scans & $\begin{array}{l}\text { Obtain baseline BMD } \\
\text { Repeat every } 1 \text { to } 2 \text { years }\end{array}$ \\
\hline $\begin{array}{l}\text { Thoracic and lumbar } \\
\text { spine } x \text {-rays }\end{array}$ & $\begin{array}{l}\text { If patient is } \geq 65 \text { years old or has kyphosis, } \\
\text { height loss } \geq 6 \mathrm{~cm} \text {, or acute severe back } \\
\text { pain: Rule out vertebral fracture }\end{array}$ \\
\hline $\begin{array}{l}\text { Lifestyle } \\
\text { modifications }\end{array}$ & $\begin{array}{l}\text { Calcium and vitamin D intake } \\
\text { Smoking cessation } \\
\text { Exercise } \\
\text { Moderating alcohol and caffeine intake }\end{array}$ \\
\hline Treatment & $\begin{array}{l}\text { Consider medical therapy to increase BMD } \\
\text { and/or reduce fracture risk }\end{array}$ \\
\hline
\end{tabular}

DXA = dual-energy $\mathrm{x}$-ray absorptiometry; $\mathrm{BMD}=$ bone mineral density. Printed with permission. Brown JP, Josse RG. CMAJ 2002;167(Suppl 10):S1. Saad F, et al. J Clin Oncol 2008;26:1.

\section{Raloxifene}

Raloxifene is a selective estrogen receptor modulator (SERM) often used to treat osteoporosis in women. In a 12-month open-label study enrolling 48 men with nonmetastatic prostate cancer receiving ADT, the addition of raloxifene $60 \mathrm{mg}$ daily significantly improved BMD at the total hip and spine. ${ }^{32}$

\section{Bicalutamide}

Bicalutamide is a nonsteroidal anti-androgen, which increases estradiol levels when given as monotherapy. A 12-month, open-label comparison of leuprolide versus bicalutamide (150 mg daily) in 52 men with nonmetastatic prostate cancer showed that bicalutamide increased $B M D$ at several sites (e.g., lumbar spine BMD $+2.5 \%$ vs. $-2.5 \%$; $p<0.001$ ), as well as decreasing fat mass, fatigue, loss of libido and hot flushes compared with leuprolide. Breast tenderness and enlargement were seen more frequently in the bicalutamide group. ${ }^{34}$ Finally, a recent prospective study whose population included 253 prostate cancer patients with osteoporosis found that bicalutamide treatment maintained BMD over 6 years. ${ }^{41}$

\section{Upcoming agents: toremifene citrate and denosumab}

The effects on BMD of toremifene citrate, a new SERM, were tested in a 6-month, placebo-controlled dose-finding study with 46 men with prostate cancer receiving ADT. An oral dose of $60 \mathrm{mg}$ daily significantly improved BMD and decreased hot flushes. ${ }^{33}$ A 2 -year, double-blind, placebocontrolled phase-III multicentre study of oral toremifene $80 \mathrm{mg}$ has been completed in 1389 ADT patients with advanced prostate cancer; this compound reduced new morphometric vertebral fractures (the primary endpoint) 
by $53 \%(p=0.034)$. Bone mineral density at lumbar spine, hip, and femur was also increased significantly $(p<0.0001)$, and lipid profiles were improved compared with placebo. ${ }^{42,43}$

Denosumab is a fully human monoclonal antibody that specifically targets RANKL and is delivered by subcutaneous injection twice a year. ${ }^{44}$ This therapy was found to be very effective in reducing fractures and was well-tolerated in the clinical settings of osteoporotic postmenopausal women ${ }^{45,46}$ and protecting BMD in osteopenic postmenopausal women receiving adjuvant aromatase inhibitors for breast cancer. ${ }^{47}$ More recently, denosumab (60 mg subcutaneously, every 6 months) was evaluated in a 36-month, phase-III, placebocontrolled randomized clinical trial involving 1468 men with nonmetastatic prostate cancer who were receiving ADT. ${ }^{48}$ Compared with placebo, denosumab significantly improved BMD at all sites measured, including lumbar spine (the primary endpoint) by $6.7 \%(p<0.001)$, total hip by $4.8 \%(p<0.001)$, femoral neck by $3.9 \%(p<0.001)$, and distal radius by $5.5 \%(p<0.001)$ at 24 months; by the end of the trial (36 months), denosumab dramatically reduced the risk of new vertebral fractures (a secondary endpoint) by $62 \%(p=0.006)$. Due to the entrance criteria of the study, the patients enrolled in the study were healthier than average prostate cancer patients in terms of BMD. Based on current knowledge in the field of osteoporosis, the impressive reduction in fracture risk reported in the pivotal denosumab study will likely be at least as impressive if one were to begin therapy in patients with low BMD and at higher risk of fractures. Denosumab was well-tolerated, with rates of serious adverse events similar to placebo.

\section{Conclusion}

Among patients with nonmetastatic prostate cancer who are receiving long-term ADT, CTIBL is a frequent, serious, and often overlooked treatment complication. Cancer-treatmentinduced bone loss can readily be detected with DXA scans, and essential measures such as calcium and vitamin D supplementation can be offered to the patient at the outset. Although, at this point, evidence is sparse for fracture reduction in this setting, BPs are most often recommended to treat CTIBL in prostate cancer. Upcoming treatments, such as denosumab and toremifene citrate, have demonstrated promise in this setting. A simple 4-step algorithm for the management of CTIBL is shown in Table 3. ${ }^{14,17}$

With the increased use of agents affecting bone metabolism and an aging population susceptible to the complications associated with CTIBL, it behooves all urologists to become more familiar with the biology, diagnosis and treatment of ADT-induced bone disease.
*Vice President Medical, St. Mary's General Hospital, Adjunct Professor of Urology, The University of Western Ontario, London, ON; Professor and Chairman of Urology, Centre hospitalier de I'Université de Montréal, Université de Montréal Endowed Chair in Prostate Cancer, Université de Montréal, Montréal, QC

Acknowledgements: Expenses associated with the preparation and submission of this manuscript were supported by an unrestricted educational grant from Amgen Inc. The authors did not receive honoraria or any other considerations from Amgen or any other source. The authors would like to thank CTC Communications Corporation, and medical writers Dr. Amy Goldwater and Arthur Tan for their assistance in the preparation of this manuscript.

Competing interests: Dr. Blair Egerdie is an advisory board member for Amgen, Astellas, Bayer HealthCare, GlaxoSmithKline and Pfizer, and is a consultant for Protox Therapeutics. Dr. Fred Saad is an advisory board member for Novartis, Amgen, AstraZeneca and sanofi-aventis.

This paper has been peer-reviewed.

\section{References}

1. Meng MV, Grossfeld GD, Sadetsky N, et al. Contemporary patterns of androgen deprivation therapy use for newly diagnosed prostate cancer. Urology 2002;60(3 Suppl 1):7-11.

2. Sharifi N, Gulley IL, Dahut WL. Androgen deprivation therapy for prostate cancer. JAMA 2005;294:238-44.

3. Jiang HX, Majumdar SR, Dick DA, et al. Development and initial validation of a risk score for predicting in-hospital and 1-year mortality in patients with hip fractures. J Bone Miner Res 2005;20:494-500.

4. Papaioannou A, Watts NB, Kendler DL, et al. Diagnosis and management of vertebral fractures in elderly adults. Am J Med 2002;113:220-8.

5. Jeldres C, Isbarn H, Capitanio U, et al. A systematic analysis of the detrimental effect of orchiectomy on the skeletal condition of men with prostate cancer. J Urology 2009;181:293.

6. Alibhai AMH, Duong-Hua $M$, Sutradhar $R$, et al. Impact of androgen deprivation therapy on cardiovascular disease and diabetes. J Clin Oncol 2009:27:3452-8.

7. Oefelein MG, Ricchiuti V, Conrad W, et al. Skeletal fractures negatively correlate with overall survival in men with prostate cancer. J Urol 2002;168:1005-7.

8. Yee EF, White RE, Murata GH, et al. Osteoporosis management in prostate cancer patients treated with androgen deprivation therapy. J Gen Intern Med 2007;22:1305-10.

9. Gruber R, Pietschmann P, Peterlik M. Introduction to bone development, remodelling and repair. In: Grampp S, ed. Radiology of Osteoporosis. $2^{\text {nd }}$ Ed. Springer, 2008.

10. Boyle WJ, Simone WS, Lacey DL. Osteoclast differentiation and activation. Nature 2003;423:337-42.

11. Hofbaver LC, Schoppet M. Clinical implications of the osteoprotegerin/RANKL/RANK system for bone and vascular diseases. JAMA 2004;292:490-5.

12. Higano CS. Androgen-deprivation-therapy-induced fractures in men with nonmetastatic prostate cancer: what do we really know? Nat Clin Pract Urol 2008:5:24-34.

13. Perez EA, Serene M, Durling FC, et al. Aromatase inhibitors and bone loss. Oncology (Williston Park) 2006;20:1029-48.

14. Brown JP, Josse RG; Scientific Advisory Council of the Osteoporosis Society of Canada. 2002 Clinical practice guidelines for the diagnosis and management of osteoporosis in Canada. CMAJ 2002;167 (Suppl 10):S1-S34.

15. Greenspan SL. Approach to the prostate cancer patient with bone disease. J Clin Endocrinol Metab 2008:93:2-7.

16. Morote J, Morin JP, Orsola A, et al. Prevalence of osteoporosis during long-term androgen deprivation therapy in patients with prostate cancer. Urology 2007;69:500-4.

17. Saad F, Adachi JD, Brown JP, et al. Cancer treatmentinduced bone loss in breast and prostate cancer. J Clin Oncol 2008:26:5465-76.

18. Brufsky AM. Cancer treatment-induced bone loss: pathophysiology and clinical perspectives. Oncologist 2008;13:187-95.

19. Shahinian VB, Kuo Y.F, Freeman JL, Goodwin JS. Risk of fracture after androgen deprivation for prostate cancer. N Engl J Med 2005;352:154-64.

20. Kahn AA, Hodsman AB, Papaioannou A, et al. Management of osteoporosis in men: an update and case example. CMAJ 2007;176:345-8. 
21. Greenspan SL, Nelson JB, Trump DL, et al. Effect of once-weekly oral alendronate on bone loss in men receiving androgen deprivation therapy for prostate cancer: a randomized trial. Ann Intern Med 2007; 146:416-24.

22. Greenspan SL, Nelson JB, Trump DL, et al. Skeletal health after continuation, withdrawal, or delay of alendronate in men with prostate cancer undergoing androgen-deprivation therapy. J Clin Oncol 2008;26:4426-34.

23. Morabito N, Gaudio A, Lasco A, et al. Neridronate prevents bone loss in patients receiving androgen deprivation therapy for prostate cancer. J Bone Miner Res 2004;19:1766-70.

24. Magno C, Anastasi G, Morabito N, et al. Preventing bone loss during androgen deprivation therapy for prostate cancer: early experience with neridronate. Eur Urol 2005;47:575-81.

25. Diamond TH, Winters J, Smith A, et al. The antiosteoporotic efficacy of intravenous pamidronate in men with prostate carcinoma receiving combined androgen blockade: a double blind, randomized, placebocontrolled crossover study. Cancer 2001;92:1444-50.

26. Smith MR, McGovern FJ, Zietman AL, et al. Pamidronate to prevent bone loss during androgen-deprivation therapy for prostate cancer. N Engl J Med 2001;345:948-55.

27. Smith MR, Eastham J, Gleason DM, et al. Randomized controlled trial of zoledronic acid to prevent bone loss in men receiving androgen deprivation therapy for nonmetastatic prostate cancer. J Urol 2003;169:2008-12.

28. Ryan $C W$, Huo $D$, Demers $L M$, et al. Zoledronic acid initiated during the first year of androgen deprivation therapy increases bone mineral density in patients with prostate cancer. J Urol 2006;176:972-8.

29. Ryan CW, Huo D, Bylow K, et al. Suppression of bone density loss and bone turnover in patients with hormone-sensitive prostate cancer and receiving zoledronic acid. BJU Int 2007;100:70-5.

30. Michaelson MD, Kaufman DS, Lee $\mathrm{H}$, et al. Randomized controlled trial of annual zoledronic acid to prevent gonadotropin-releasing hormone agonist-induced bone loss in men with prostate cancer. J Clin Oncol 2007;25:1038-42.

31. Israeli RS, Rosenberg SJ, Saltzstein DR, et al. The effect of zoledronic acid on bone mineral density in patients undergoing androgen deprivation therapy. Clin Genitourin Cancer 2007:5:271-7.

32. Smith MR, Fallon MA, Lee $\mathrm{H}$, et al. Raloxifene to prevent gonadotropin-releasing hormone agonistinduced bone loss in men with prostate cancer: a randomized controlled trial. J Clin Endocrinol Metab 2004;89:3841-6.

33. Steiner MS, Patterson A, Israeli R, et al. Toremifene citrate versus placebo for treatment of bone loss and other complications of androgen deprivation therapy in patients with prostate cancer. ASCO Annual Meeting Proceedings (Post-Meeting Edition). J Clin Oncol 2004;22(Suppl):4597.

34. Smith MR, Goode M, Zietman AL, et al. Bicalutamide monotherapy versus leuprolide monotherapy for prostate cancer: effects on bone mineral density and body composition. J Clin Oncol 2004;22:2546-53.
35. Smith MR. Androgen deprivation therapy for prostate cancer: new concepts and concerns. Curr Opin Endocrinol Diabetes Obes 2007;14:247-54.

36. Boonen S, Vanderschueren D, Venkek K, et al. Recent developments in the management of postmenopausal osteoporosis with bisphosphonates: enhanced efficacy by enhanced compliance. I Intern Med 2008;264:315-32.

37. Conte P, Guarneri V. Safety of intravenous and oral bisphosphonates and compliance with dosing regimens. Oncologist 2004;9(Suppl 4):28-37.

38. Khosla S, Burr D, Cauley J, et al. Bisphosphonate-associated osteonecrosis of the jaw: report of a task force of the American Society for Bone and Mineral Research. J Bone Miner Res 2007;22:1479-91.

39. Aapro M, Abrahamsson PA, Body JJ, et al. Guidance on the use of bisphosphonates in solid tumours: recommendations of an international expert panel. Ann Oncol 2008;19:420-32.

40. Polascik TJ. Bone health in prostate cancer patients receiving androgen-deprivation therapy: the role of bisphosphonates. Prostate Cancer Prostatic Dis 2008;11:13-9.

41. Wadhwa VK, Weston R, Mistry R, et al. Long-term changes in bone mineral density and predicted fracture risk in patients receiving androgen-deprivation therapy for prostate cancer, with stratification of treatment based on presenting values. BJU Int 2009;104:800-5.

42. Smith MR, Malkowicz SB, Chu F, et al. Toremifene improves lipid profiles in men receiving androgendeprivation therapy for prostate cancer: interim analysis of a multicenter phase III study. J Clin Oncol 2008;26:1824-9.

43. GTx: Toremifene citrate $80 \mathrm{mg}$ meets primary and key endpoints in Phase III trial in advanced prostate cancer patients on androgen deprivation therapy [press release]. New York, NY: Thomson Reuters; February 25, 2008

44. Schwarz EM, Ritchlin CT. Clinical development of anti-RANKL therapy. Arthritis Res Ther 2007;9(Supp|1):S7.

45. McClung MR, Lewiecki EM, Cohen SB, et al. Denosumab in postmenopausal women with low bone mineral density. N Engl J Med 2006;354:821-31.

46. Cummings SR, San Martin J, McClung MR, et al. Denosumab for prevention of fractures in postmenopausal women with osteoporosis. N Engl J Med 2009;361:756-65.

47. Ellis $G K$, Bone $H G$, Chlebowski $R$, et al. Randomized trial of denosumab in patients receiving adjuvant aromatase inhibitors for nonmetastatic breast cancer. J Clin Oncol 2008;26:4875-82.

48. Smith MR, Egerdie B, Hernàndez Toriz N, et al. Denosumab in men receiving androgen-deprivation therapy for prostate cancer. N Engl J Med 2009;361:745-55.

Correspondence: Dr. Fred Saad, Université de Montréal, Directeur, Urologie-Oncologie, CHUM, 1560 Sherbrooke St. E., Montréal QC H2L 4M1; Email: fredsaad@videotron.ca 